Volume 10 Issue 2, April-June 2016: pp. 221-412. Copyright (C) 2015-2016 FIAT JUSTISIA. Faculty of Law, Lampung University, Bandarlampung, Lampung, Indonesia.

ISSN: 1978-5186 | e-ISSN: 2477-6238.

Open Access: http://jurnal.fh.unila.ac.id/index.php/fiat

Fiat Justisia is licensed under a Creative Commons Attribution 4.0 International License, which permits unrestricted use, distribution, and reproduction in any medium, provided the original work is properly cited.

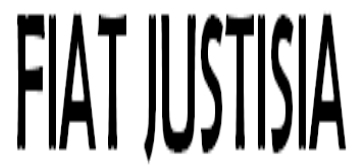

\title{
IMPLEMENTASI REHABILITASI TERHADAP ANAK PENYALAH GUNA NARKOTIKA (Studi di Wilayah Kepolisian Daerah Lampung)
}

\section{The Implementation of Rehabilitation on Under Age Narcotics Users}

\author{
Ibrahim Fikma Edrisy \\ Sekolah Tinggi Ilmu Hukum Kotabumi \\ email: ibrahimfikmaedrisy@gmail.com
}

\begin{abstract}
The implementation of rehabilitation on underage narcotics users based on state regulation of narcotics, an addicts narcotics users is obliged to take a rehabilitation process, but this policy has never been applied, most of the underage narcotics users were sentenced to be put in jail than taking rehabilitation. The formulation of the problem in this thesis is: why is the implementation of rehabilitation on underage narcotics users so low. What is the problem with implementing rehabilitation on underage narcotics users? What do the police at Polda Lampung do on underage narcotics users? The result of the research show that the implementation of rehabilitation on underage narcotics users is not in line with state regulations, they are government policy, policy of health minister on technical regulation on medical rehabilitation for the drugs addicts, drugs users, and victim of drugs users, which stated that the underage narcotics users is supposed to be put in rehabilitation but this rule has never been applied on, most of the underage narcotics users were put in jail than on rehabilitation. The problem on rehabilitation is affected by some factors like law structure of Direktorat Narkoba Polda Lampung on the implementation of rehabilitation is not optimal, law culture on the level of obedience of the society about the law is not optimal, and the effort of Kepolisian Daerah Lampung in solving the underage narcotics users is through preemptive, preventive, and repressive way.
\end{abstract}

Keywords: Rehabilitation, Under Age, Narcotics 


\begin{abstract}
Abstrak
Pelaksanaan rehabilitasi pengguna narkotika di bawah umur berdasarkan peraturan negara narkotika, pengguna pecandu narkotika wajib mengambil proses rehabilitasi, tetapi kebijakan ini belum pernah diterapkan, sebagian besar narkotika di bawah umur pengguna dihukum untuk diletakkan di penjara daripada mengambil rehabilitasi. Rumusan masalah dalam skripsi ini adalah: mengapa pelaksanaan rehabilitasi pada narkotika pengguna di bawah umur sangat rendah. Apa masalah dengan melaksanakan rehabilitasi pada pengguna narkotika di bawah umur? Apa yang polisi di Polda Lampung lakukan pada pengguna narkotika di bawah umur? Hasil penelitian menunjukkan bahwa pelaksanaan rehabilitasi pada pengguna narkotika di bawah umur tidak sejalan dengan peraturan negara, mereka kebijakan pemerintah, kebijakan menteri kesehatan pada regulasi teknis rehabilitasi medis untuk pecandu obat, pengguna narkoba, dan korban narkoba pengguna, yang menyatakan bahwa pengguna narkotika di bawah umur seharusnya dimasukkan ke dalam rehabilitasi tapi aturan ini belum pernah diterapkan pada, sebagian besar pengguna narkotika di bawah umur yang dimasukkan ke dalam penjara dari pada rehabilitasi. Masalah rehabilitasi dipengaruhi oleh beberapa faktor seperti struktur hukum Direktorat Narkoba Polda Lampung pada pelaksanaan rehabilitasi tidak optimal, budaya hukum pada tingkat kepatuhan masyarakat tentang hukum tidak optimal, dan upaya Kepolisian Daerah Lampung dalam memecahkan pengguna narkotika di bawah umur adalah melalui cara preemptive, preventif, dan represif.
\end{abstract}

\title{
Kata Kunci: Rehabilitasi, di Bawah Umur, Narkotika
}

\section{A. Pendahuluan}

Narkotika diperlukan oleh manusia untuk pengobatan sehingga untuk memenuhi kebutuhan dalam bidang pengobatan dan studi ilmiah diperlukan suatu produksi narkotika yang terus menerus untuk para penderita tersebut. Pada awalnya penggunaan dan penyalahgunaan narkotika terbatas pada dunia kedokteran, namun penggunaannya dewasa ini meningkat terutama di kalangan generasi muda. Maraknya peredaran dan penyalahgunaan narkotika, diakui banyak kalangan menjadi ancaman yang sangat berbahaya bagi bangsa Indonesia. ${ }^{1}$

Pengaturan ketersediaan narkotika bertujuan untuk mencegah dan menghindari adanya penyalahgunaan dan peredaran gelap narkotika. Penyalahgunaan narkotika dapat diartikan sebagai pemakaian narkotika secara tetap yang tujuannya bukan untuk pengobatan, atau yang digunakan

\footnotetext{
${ }^{1}$ Makarao, Moh. Taufik, Suhasril, dan A.S., Moh. Zakky. (2003). Tindak Pidana Narkotika. Jakarta: Ghalia Indonesia, p. 10
} 
tanpa mengikuti aturan takaran pemakaian. Masalah penyalahgunaan narkotika bukan saja merupakan masalah yang perlu mendapat perhatian bagi negara Indonesia, melainkan juga bagi dunia Internasional. Memasuki abad ke-20 perhatian dunia internasional terhadap masalah narkotika semakin meningkat, salah satu dapat dilihat melalui Single Convention on Narcotic Drugs pada tahun 1961.2 Masalah ini menjadi begitu penting mengingat bahwa obat-obat (narkotika) itu adalah suatu zat yang dapat merusak fisik dan mental yang bersangkutan, apabila penggunanya tanpa resep dokter.

Pembangunan nasional tidak bisa dihindari dari kehidupan manusia sebagai sarana utama. Sumber daya manusia hal yang paling penting dalam melaksanakan pembangunan karena pembangunan tidak akan berjalan tanpa dilandasi dengan sumber daya manusia yang berkualitas. Oleh karena itu, pembangunan sumber daya manusia menjadi prioritas. Dengan meningkatnya kualitas sumber daya manusia, dapat menjadikan modal dalam berkompetisi diera globalisasi saat ini.

Penyalahgunaan narkotika, psikotropika, dan zat adiktif lainnya akhirakhir ini semakin marak di Indonesia. Adapun yang di maksud narkotika menurut Undang-Undang Nomor 35 Tahun 2009 tentang Narkotika Pasal 1 angka 1 adalah:

"Narkotika adalah zat atau obat yang berasal dari tanaman atau bukan tanaman, baik sintetis maupun semi sintetis yang dapat menyebabkan penurunan atau perubahan kesadaran, hilangnya rasa, mengurangi sampai menghilangkan rasa nyeri, dan dapat menimbulkan ketergantugan, yang dibedakan dalam golongangolongan sebagaimana terlampir dalam undang-undang ini."

Pecandu pada dasarnya adalah korban penyalahgunaan narkotika yang melanggar peraturan pemerintah, dan mereka adalah warga negara Indonesia yang diharapkan dapat membangun negeri ini dari keterpurukan hampir di segala bidang. ${ }^{3}$ Berkaitan dengan masalah penyalahgunaan narkotika tersebut, diperlukan suatu kebijakan hukum pidana yang memposisikan pecandu narkotika sebagai korban, bukan pelaku kejahatan.

Implementasi rehabilitasi merupakan realisasi dari sebuah aturan, hal ini sangat penting karena dengan sebuah implementasi dapat diketahui apakah suatu aturan tersebut sudah benar-benar terlaksana atau tidak. Undang-undang Nomor 35 Tahun 2009 tentang narkotika telah memberi perlakuan yang berbeda bagi pelaku penyalahguna narkotika, sebelum undang-undang ini berlaku tidak ada perlakuan yang berbeda antara

\footnotetext{
${ }^{2}$ Adi, Kusno. (2009). Kebijakan Kriminal Dalam Penanggulangan Tindak Pidana Narkotika Oleh Anak. Malang: UMM Press, p. 30.

${ }^{3}$ Makarao, Moh. Taufik, Suhasril, dan A.S, Moh. Zakky. Op.Cit. p. 74-75.
} 
pengguna, pengedar, bandar maupun produsen narkotika. Pengguna atau pecandu narkotika di satu sisi merupakan pelaku tindak pidana, namun di sisi lain merupakan korban. ${ }^{4}$

Kenyataannya menunjukkan penjatuhan vonis oleh hakim dalam perkara narkotika masih belum efektif pelaksanaannya. Sebagian besar pecandu narkotika tidak dijatuhi vonis rehabilitasi sesuai yang disebutkan dalam undang-undang narkotika melainkan dijatuhi vonis penjara meskipun ketentuan Undang-Undang menjamin pengaturan upaya rehabilitasi, baik itu rehabilitasi medis maupun rehabilitasi sosial bagi penyalahguna dan pecandu narkotika. Dalam Undang-Undang Narkotika ketentuan hukum yang mengatur mengenai rehabilitasi terhadap pecandu narkotika diatur dalam Pasal 54, pasal 56, Pasal 103, dan dikaitkan dengan Pasal 127 UndangUndang Narkotika. Hal yang menarik dalam Undang-Undang Narkotika terdapat dalam Pasal 103 dimana kewenangan hakim untuk menjatuhkan vonis/sanksi bagi seseorang yang terbukti sebagai pecandu narkotika untuk menjalani rehabilitasi.

Setiap penyalahguna narkotika untuk yang menggunakan ketentuan pidananya diatur dalam pasal 127 UU No. 35 Tahun 2009 tentang Narkotika. Di dalam Pasal 127 diatur bahwa bagi setiap penyalahguna narkotika diancam dengan pidana penjara sedangkan bagi pecandu narkotika dan korban penyalahguna narkotika ditempatkan di lembaga rehabilitasi medis dan rehabilitasi sosial.

Upaya penanggulangan kejahatan yang tepat sebaiknya tidak hanya terfokus pada berbagai hal yang berkaitan dengan penyebab timbulnya kejahatan tetapi metode apa yang efektif dipergunakan dalam penaggulangan kejahatan. ${ }^{5}$ Pemberian rehabilitasi terhadap penyalahguna narkotika dianggap perlu untuk menekan penggunaan terhadap narkotika dan obatobatan terlarang.

Anak adalah bagian dari generasi muda sebagai salah satu sumber daya manusia yang merupakan potensi dan penerus cita-cita perjuangan bangsa, yang memiliki peranan strategis, mempunyai ciri dan sifat khusus, memerlukan pembinaan dan perlindungan dalam rangka menjamin pertumbuhan dan perkembangan fisik, mental, dan sosial secara utuh, serasi, selaras, dan seimbang. Sebagai generasi penerus bangsa pada kenyataan pada saat ini tidak sedikit anak-anak bangsa terjerumus ke hal-hal yang tidak mendorong mereka tumbuh sebagai anak bangsa yang berkualitas, salah satu yang menjadi penghambat perkembangan anak yaitu penyalagunaan narkotika di kalangan anak. Keberadaan anak perlu mendapatkan perhatian,

${ }^{4}$ Adi, Kusno. (2009). Diversi Sebagai Upaya Alternatif Penanggulangan Tindak Pidana Narkotika Oleh Anak, Malang: UMM Press, p. 3.

${ }^{5}$ AR., Sujono dan Bony, Daniel. (2011). Komentar dan Pembahasan Undang-undang Nomor 35 Tahun 2009 tentang Narkotika. Jakarta: Sinar Grafika, p. 33. 
dalam perkembangannya ke arah dewasa, terkadang melakukan perbuatan yang lepas kontrol, mereka melakukan perbuatan melawan hukum sehingga dapat merugikan orang lain atau merugikan dirinya sendiri.

Tingkah laku yang demikian disebabkan karena dalam masa pertumbuhan sikap dan mental anak belum stabil, dan juga tidak terlepas dari lingkungan pergaulannya. Sudah banyak contoh karena lepas kendali, kenakalan anak sudah menjadi tindak pidana atau kejahatan, sehingga perbuatan tersebut tidak dapat ditolerir. Anak yang melakukan kejahatan harus berhadapan dengan aparat penegak hukum untuk mempertanggumg jawabkan perbuatannya.

Anak yang melakukan tindakan pidana dalam hukum pidana yang berlaku di Indonesia harus dipertanggungjawabkan atas perbuatannya. Pelaku anak masih dibawah umur, maka proses penegakan hukum dan pemidanaan yang diterapkan kepada anak dilaksanakan secara khusus, mengingat usia mereka masuk dalam kategori di bawah umur. ${ }^{6}$

Menurut Pasal 1 Ayat (7) Undang-Undang Nomor 11 Tahun 2012 tentang Sistem Peradilan Pidana Anak dinyatakan bahwa diversi adalah pengalihan penyelesaian perkara anak dari proses peradilan pidana ke proses di luar peradilan pidana. Pengertian Restoratif tercantum dalam Pasal 1 Ayat (6) Undang-Undang Sistem Peradilan Pidana Anak yang isisnya bahwa keadilan restoratif adalah penyelesaian perkara tindak pidana dengan melibatkan pelaku, korban, keluarga pelaku/korban dan pihak lain yang terkait untuk bersama-sama mencari penyelesaian yang adil dengan menekankan pemulihan kembali pada keadaan semula, dan bukan pembalasan.

Pasal 6 Undang-Undang Nomor 11 Tahun 2012 Tentang Sistem Peradilan Pidana Anak menyebutkan diversi bertujuan :

1. Mencapai perdamaian antara korban dan anak

2. Menyelesaikan perkara anak di luar proses peradilan

3. Menghindarkan anak dari perampasan kemerdekaan

4. Mendorong masyarakat untuk berpartisipasi

5. Menanamkan rasa tanggung jawab kepada anak

Pembaharuan hukum pidana dilihat dari sudut pendekatan kebijakan sebagai bagian dari kebijakan sosial, artinya bagian dari upaya mengatasi masalah-masalah sosial (termasuk didalamnya masalah kemanusiaan) dalam rangka mencapai/menunjang tujuan nasional yaitu kesejahteraan masyarakat, selain itu sebagai bagian dari kebijakan kriminal, artinya bagian dari upaya perlindungan masyarakat (khususnya upaya penanggulangan kejahatan), khususnya kejahatan atau tindak pidana yang dilakukan oleh anak dibawah umur.

\footnotetext{
${ }^{6}$ Gosita, Arif. (2009). Masalah Perlindungan Anak. Bandung: Mandar Maju, p. 43.
} 
Berdasarkan data kasus Narkotika yang ditangani Polda Lampung, perkara Narkotika dari Tahun 2014 sebanyak 306 kasus, Tahun 2015 sebanyak 220 kasus, 2016 sebanyak 80 kasus dan kasus penyalahguna dewasa yang direhabilitasi 2014 sebanyak 1 kasus, 2015 sebanyak 21 kasus, 2016 sebanyak 6 kasus, dan terdapat kasus Narkotika terhadap anak yang direhabilitasi tahun 2014-2015 dengan total 19 kasus. Walaupun secara jelas rehabilitasi diatur oleh Undang-Undang Nomor 35 Tahun 2009 Tentang Narkotika, tapi praktiknya jauh dari pelaksanaan yang sebenarnya anak yang melakukan penyalahgunaan Narkotika seharusnya di rehabilitasi karena mengingat anak yang berkonflik dengan hukum harus memiliki pembinaan karena memiliki masa depan, akan tetapi anak yang dibawah umur malah dibawa ke dalam sistem peradilan yang seharusnya anak tersebut pada tahap kepolisian seharusnya diupayakan dan dilakukan diversi secara restorative justice untuk menghindari anak tersebut kemudian hari tidak melakukan perbuatan yang sama dan memperbaiki mental anak tersebut.

Pengaturan rehabilitasi atas pecandu narkotika menunjukkan adanya kebijakan hukum pidana yang bertujuan agar penyalahguna dan pecandu narkotika tidak lagi menyalahgunakan narkotika tersebut. Rehabilitasi merupakan suatu alternatif pemidanaan yang tepat untuk para pecandu narkotika, yang patut didukung dengan peraturan pelaksanaan yang mengakomodir hak bagi para penyalahguna dan pecandu narkotika.

Berdasarkan latar belakang di atas, maka permasalahan dalam penelitian ini dirumuskan sebagai berikut : 1) Mengapa implementasi rehabilitasi terhadap anak penyalah guna narkotika di Wilayah Hukum Kepolisian Daerah Lampung sangat rendah?; 2) Apakah hambatan implementasi rehabilitasi Kepolisian Daerah Lampung terhadap anak penyalah guna narkotika?; 3) Bagaimana upaya Kepolisian Daerah Lampung mengatasi kendala rehabilitasi terhadap anak penyalah guna narkotika? Penelitian ini menggunakan pendekatan secara yuridis normatif dan yuridis empiris.

\section{B. Pembahasan}

\section{Implementasi Rehabilitasi Terhadap Anak Penyalah Guna Narkotika Di Wilayah Hukum Kepolisian Daerah Lampung Sangat Rendah}

Melihat peredaran kasus Narkotika yang semakin meningkat, dan sangat membahayakan bagi generasi muda yang akan datang, perderan narkotika juga sangat membahayakan dan sangat mudah untuk didapatkan, serta para penyalahguna narkotika setiap tahun nya semakin meningkat seperti data yang didapatkan di Direktorat Narkoba Polda Lampung, data anak penyalahguna narkotika tahun 2014 yaitu 118 kasus, tahun 2015 yaitu 159 kasus, tahun 2016 yaitu 42 kasus, serta yang direhabilitasi tahun 2014 yaitu 
12 kasus, tahun 2015 yaitu 7 kasus, melihat angka penyalahguna narkotika yang semakin banyak dan meningkat pada anak, tetapi anak yang direhabilitasi sangat sedikit padahal bagi anak yang menyalahgunakan narkotika wajib untuk direhabilitasi.

Penggunaan Narkotika bagi diri sendiri mengandung arti bahwa penggunaan narkotika tersebut tanpa melalui pengawasan dokter dianggap merupakan suatu perbuatan "tanpa hak dan melawan hukum". Dikeluarkan UndangUndang Nomor 35 tahun 2009 mengatur ketentuan mengenai putusan memerintahkan untuk menjalani rehabilitasi bagi pengguna narkotika pada Pasal 54 dan Pasal 103 :

Pasal 54

Pecandu narkotika dan korban penyalahgunaan narkotika wajib menjalani rehabilitasi medis dan rehabilitasi sosial.

Pasal 103

(1) Hakim yang memeriksa perkara pecandu narkotika dapat:

a. Memutuskan untuk memerintahkan yang bersangkutan menjalani pengobatan dan/atau perawatan, apabila pecandu narkotika tersebut terbukti bersalah melakukan tindak pidana narkotika; atau

b. Menetapkan untuk memerintahkan yang bersangkutan menjalani pengobatan dan/atau perawatan, apabila pecandu narkotika tersebut tidak terbukti bersalah melakukan tindak pidana narkotika.

(2) Masa menjalani pengobatan dan/atau perawatan bagi pecandu narkotika sebagaimana dimaksud dalam ayat (1) huruf a, diperhitungkan sebagai masa menjalani hukuman.

Double track system dalam perumusan sanksi terhadap penyalahgunaan narkotika merupakan kebijakan hukum pidana dalam formulasi ketentuan-ketentuan yang mengatur mengenai sanksi yang diberikan kepada pelaku penyalahgunaan narkotika, yaitu berupa sanksi pidana dan sanksi tindakan mengingat pelaku penyalahgunaan narkotika memiliki posisi yang sedikit berbeda dengan pelaku tindak pidana lainnya. Di satu sisi ia merupakan pelaku tindak pidana yang harus dihukum, namun di sisi lain merupakan korban dari tindak pidana yang dilakukannya itu sendiri, sehingga perlu dilakukan suatu tindakan berupa rehabilitasi.

Penentuan sanksi terhadap pecandu narkotika, apakah akan diterapkan sanksi pidana atau sanksi tindakan rehabilitasi dimana dalam hal ini penentuan tersebut berada di tangan hakim. Sebab berdasarkan ketentuan undang-undang narkotika, hakim diberikan kewenangan untuk menentukan dan menjatuhkan pidana penjara atau tindakan rehabilitasi terhadap pecandu narkotika tersebut, untuk menentukan apakah dalam menangani perkara pecandu narkotika, hakim akan menerapkan ketentuan Pasal 127 (mengatur 
mengenai sanksi pidana) atau menerapkan ketentuan Pasal 103 (mengatur mengenai sanksi tindakan "rehabilitasi") adalah pada akhirnya bermuara kepada keyakinan hakim apakah pelaku penyalahgunaan narkotika tersebut tepat untuk dikatakan sebagai pecandu yang harus direhabilitasi atau lebih tepat dikatakan sebagai pelaku tindak pidana penyalahgunaan narkotika yang harus dipidana penjara adalah dengan berdasarkan hasil keterangan laboratorium yang menyatakan bahwa pelaku tersebut mengalami ketergantungan terhadap narkotika sehingga memerlukan proses perawatan dan atau pengobatan yang dilakukan melalui fasilitas rehabilitasi dan yang tentunya berdasarkan ketentuan undang-undang.

Berdasarkan hasil wawancara dengan Prianto Teguh Nugroho, selaku Kabag Binopsnal Reserse Narkoba Polda Lampung menjelaskan bahwa dalam pelaksanaan Rehabilitasi memperhatikan Undang-undang Nomor 35 Tahun 2009 mengenai penerapan tindakan rehabilitasi, yaitu:

Pasal 56

(1) Rehabilitasi medis Pacandu Narkotika dilakukan di rumah sakit oleh Menteri

(2) Lembaga rehabilitasi tertentu diselenggarakan oleh instansi pemerintah atau masyarakat dapat melakukan rehabilitasi medis Pecandu Narkotika setelah mendapat persetujuan Menteri.

Pasal 57

Selain melalui pengobatan dan /atau rehabilitasi medis, penyembuhan Pecandu Narkotika dapat diselanggarakan oleh instansi pemerintah atau masyarakat melalui pendekatan keagaman dan tradisional.

Pasal 58

Rehabilitasi sosial mantan Pecandu Narkotika diselanggarakan baik oleh instansi pemerintah maupun oleh masyarakat.

Menurut Kabag Binopsnal Direktorat Reserse Narkoba Polda Lampung ketentuan pidana terhadap penyalahgunaan narkotika tersebut yaitu di dalam Undang-Undang Nomor 35 Tahun 2009 mengatur mengenai pidana minimum dan maksimum. Didalam Undang-Undang Nomor 35 Tahun 2009 ketentuan pidana terhadap penyalahgunaan narkotika di dalam menerapkan ketentuan pidana tersebut juga langsung diikuti dengan kewajiban untuk memperhatikan ketentuan Pasal 103 mengenai rehabilitasi terhadap pecandu narkotika yang dimuat di dalam ketentuan ayat (2). Undang-Undang Nomor 35 tahun 2009 memberikan peluang yang lebih besar bagi pecandu narkotika untuk divonis menjalani rehabilitasi yang diperhitungkan sebagai masa menjalani hukuman.

Selanjutnya Kabag Binopsnal Direktorat Polda Lampung menambahkan dalam menerapkan proses rehabilitasi terhadap pelaku tindak pidana penyalahgunaan narkoba, Polda Lampung dan Jajaran tetap 
memperhatikan azas legalitas, sebelum seseorang pelaku ditempatkan di lembaga rehabilitasi maka diadakan assessment oleh Tim Assesment terpadu yang terdiri dari beberapa unsure intansi. Tim assessment dibagi 2 (dua) menjadi Tim Dokter (BNN dan Dinas Kesehatan) dan Tim Hukum (Polda dan Kejaksaan), hasil dari assesmen tersebut menjadi acuan apakah seseorang pelaku tersebut di tempatkan dilembaga rehabilitasi medis atau Pro justitia (berkas perkara lanjut), jadi tidak semua pelaku yang dilakukan assessment pasti menjalani rehabilitasi.

Berdasarkan hasil wawancara dengan Eddy Rifai selaku Akademisi Universitas Lampung mengenai implementasi rehabilitasi terhadap anak penyalahguna narkotika, menjelaskan bahwa implementasi rehabiltasi terhadap anak penyalahguna narkotika wajib dilakukan mengingat sudah diatur didalam Undang-Undang Narkotika Nomor 35 Tahun 2009, dimana Eddy Riffai mengemukakan melihat anak yang menyalahgunakan narkotika seharusnya harus lebih dipertimbangkan dan lebih besar untuk direhabilitasi mengingat anak di dalam Undang-Undang Narkotika sendiri dan didalam Undang-Undang Sistem Peradilan Pidana Anak sendiri memungkinkan untuk anak di rehabilitasi dan banyak peraturan lainnya yang menekankan untuk anak dapat direhabilitasi.

Selanjutnya menurut Eddy Riffai selaku Akademisi Universitas Lampung menambahkan kembali bahwa terhadap anak didalam implementasi rehabilitasi di Peradilan itu sudah diatur didalam Sistem Peradilan Pidana Anak, tetapi dalam prakteknya di setiap instansi berbedabeda penerapannya dan ukurannya didalam implementasi rehabilitasi, karena mengingat masalah tempat rehabilitasi dan setiap instantsi memiliki perbedaan-perbedaan didalam melakukan implementasi rehabilitasinya.

Berdasarkan paparan dari narasumber diatas, dapat dianalisis bagi anak yang menyalahgunakan narkotika dapat direhabilitasi, mengingat banyak aturan mengenai anak yang berkonflik dengan hukum dan aturan lainnya yang mengusahakan anak direhabilitasi seperti didalam peraturan Undang-Undang Narkotika, Undang-Undang Sistem Peradilan dan UndangUndang Pengadilan Anak.

Pecandu narkotika menurut Undang-undang Narkotikai di satu sisi merupakan pelaku tindak pidana penyalahgunaan narkotika adalah dengan adanya ketentuan Undang-undang narkotika yang mengatur mengenai pidana penjara yang diberikan kepada para pelaku penyalahgunaan narkotika kemudian, di sisi lainnya dapat dikatakan bahwa menurut Undang-undang narkotika, pecandu narkotika tersebut merupakan korban adalah ditunjukkan dengan adanya ketentuan bahwa terhadap pecandu narkotika dapat dijatuhi vonis rehabilitasi. Hal ini berarti Undang-undang di satu sisi masih menganggap pecandu narkotika sebagai pelaku tindak pidana, dan di sisi lain merupakan korban dari penyalahgunaan narkotika yang dilakukan. 
Batas-batas perlindungan hak asasi dalam Undang-Undang Narkotika Dalam batas - batas yang dimungkinkan perlindungan terhadap hak-hak asasi warga masyarakat Indonesia, terhadap beberapa prinsip yang terkandung dalam Undang-undang narkotika adalah :

a. Bahwa Undang-undang narkotika juga dipergunakan untuk menegaskan ataupun menegakkan kembali nilai - nilai sosial dasar prilaku hidup masyarakat dalam negara kesatuan Republik Indonesia yang dijiwai oleh falsafah Negara Pancasila.

b. Bahwa Undang-undang narkotika merupakan satu-satunya produk hukum yang membentengi bagi pelaku tindak pidana narkotika secara efektif.

c. Dalam menggunakan produk hukum lainnya, harus diusahakan dengan sungguh-sungguh bahwa caranya seminimal mungkin tidak mengganggu hak dan kewajiban individu tanpa mengurangi perlindungan terhadap kepentingan masyarakat yang demokrasi dan modern.

Beradasarkan wawancara dengan Kabag Binopsnal Reserse Polda Lampung $^{7}$, rehabilitasi harus memperhatikan dasar-dasar penguat seperti Undang-Undang Narkotika 35 Tahun 2009, Undang-Undang Nomor 11 Tahun 2012 Tentang Sistem Peradilan Pidana Anak serta Undang-Undang Nomor 23 Tahun 2014 Tentang Perlindungan Anak, dimana Dalam Undangundang Nomor 35 Tahun 2009 ini meliputi segala kegiatan dan perbuatan yang berhubungan dengan narkotika, yaitu:

a. Narkotika sbagaimana di maksud dalam Pasal 5 di golongan ke dalam :

1) Narkotika Golongan I;

2) Narkotika Golongan II;

3) Narkotika Golongan III;

b. Penggolongan Narkotika sebagaimana dimaksud pada ayat (1) untuk pertama kali ditetapkan sebagaimana tercantum dalam lampiran 1 dan merupakan bagian yang tak terpisahkan dari Undang-undang ini.

c. Ketentuan mengenai perubahan penggolongan Narkotika sebagaimana dimaksud pada ayat (2) diatur dengan Peraturan Menteri.

Rehabilitasi bagi pecandu dan korban penyalahgunaan narkotika ini memang diharapkan dapat menyelamatkan hidup dari pecandu dan korban penyalahgunaan narkotika itu sendiri. Sehingga penerapan rehabilitasi itu sendiri haruslah dimanfaatkan semaksimal mungkin. Hal ini juga mendapatkan dukungan dari pemerintah dengan mengeluarkan beberapa aturan yang mengatur mengenai rehabilitasi itu sendiri. Adapun aturan yang mengatur dan membahas mengenai rehabilitasi adalah sebagai berikut:

a. Undang-Undang Republik Indonesia Nomor 35 Tahun 2009 tentang Narkotika.

\footnotetext{
${ }^{7}$ Wawancara Kabag Binopsnal Dir Narkoba Kepolisian Daerah Lampung, AKBP Prianto Teguh Nugroho, SIK., Senin, Tanggal 04 April 2016
} 
b. Surat Edaran Mahkamah Agung (SEMA) Nomor 4 Tahun 2010 tentang Penempatan Penyalahguna, Korban Penyalahguna Kedalam Lembaga Medis dan Sosial.

c. Peraturan Pemerintah (PP) Nomor 25 Tahun 2011 tentang Pelaksanaan Wajib Lapor Pecandu Narkotika untuk mendapatkan layanan terapi dan Rehabilitasi.

d. Peraturan Menteri Kesehatan Republik Indonesia Nomor 80 Tahun 2014 tentang petunjuk teknis pelaksanaan rehabilitasi medis bagi pecandu, penyalahguna, dan korban penyalahgunaan Narkotika yang sedang dalam proses penyidikan, penuntutan dan persidangan atau telah mendapatkan penetapan/putusan pengadilan.

e. Keputusan Menteri Kesehatan (kepmenkes) Nomor 1305/menkes/SK/VI/2011 yang menunjuk 131 Instansi Penerima Wajib Lapor (IPWL) di 33 Provinsi.

f. Peraturan Bersama Ketua Mahkamah Agung Republik Indonesia, Menteri Hukum dan Hak Asasi Manusia Republik Indonesia, Menteri Kesehatan Republik Indonesia, Jaksa Agung Republik Indonesia, Kepala Kepolisian Negara Republik Indonesia, Kepala Badan Narkotika Nasional Republik Nomor 01/ PB / MA/III/2014, Nomor 03 Tahun 2014, Nomor PER-005/A/JA/03/2014, Nomor 1 Tahun 2014, Nomor PERBER/01/III/2014/BNN tentang Penanganan Pecandu Narkotika dan Korban Penyalahgunaan Narkotika ke dalam Lembaga Rehabilitasi.

Tentunya banyaknya aturan belum dapat menjamin efektifnya suatu kebijakan. Khususnya penerapan pasal 54 Undang-Undang Republik Indonesia Nomor 35 Tahun 2009 tentang Narkotika yang menyatakan bahwa: "Pecandu Narkotika dan Korban penyalahgunaan Narkotika wajib menjalani rehabilitasi medis dan rehabilitasi sosial". Walaupun dalam pasal tersebut tertera dengan jelas bahwa pecandu dan korban penyalahgunaan narkotika wajib untuk direhabilitasi namun pada kenyataannya hal tersebut masih sangat kurang. Hal ini dapat dilihat dari tabel berikut:

Tabel: Data Anak dan Dewasa Penyalahguna Narkotika serta Rehabilitasi Pada Polda Lampung Tahun 2014-2016 ${ }^{8}$

\begin{tabular}{|l|l|r|r|r|}
\hline \multirow{2}{*}{ No. } & \multirow{2}{*}{ Kasus } & \multicolumn{3}{|c|}{ Kesatuan Polda Lampung } \\
\cline { 3 - 5 } & & \multicolumn{3}{|c|}{ Tahun } \\
\cline { 3 - 5 } & & $\mathbf{2 0 1 4}$ & $\mathbf{2 0 1 5}$ & $\mathbf{2 0 1 6}$ \\
\hline 1. & Tersangka Anak & 118 & 159 & 42 \\
\hline
\end{tabular}

\footnotetext{
${ }^{8}$ Kepolisian Negara Republik Indonesia Daerah Lampung Direktorat Reserse Narkoba. Tahun 2016.
} 


\begin{tabular}{|l|l|r|r|r|}
\hline 2. & Anak Rehabilitasi & 12 & 7 & - \\
\hline 3. & Tersangka Dewasa & 306 & 220 & 80 \\
\hline 4. & Dewasa Rehabilitiasi & 1 & 21 & 6 \\
\hline
\end{tabular}

Dari data diatas menunjukkan bahwa jumlah orang yang direhabilitasi berdasarkan putusan masih sangat rendah. Padahal begitu banyak orang tergolong sebagai pecandu namun tidak direhabilitasi. Hal ini tentunya berlawanan dengan Pasal 54 Undang-Undang Republik Indonesia Nomor 35 tahun 2009 tentang Narkotika yang mewajibkan bagi pecandu dan korban penyalahgunaan narkotika untuk direhabilitasi.

Berdasarkan paparan dari narasumber maka menurut penulis implementasi rehabilitasi terhadap anak penyalahguna narkotika di Wilayah Hukum Kepolisian Daerah Lampung sangat rendah adalah dimana hakim didalam memutus dan menentukan perkara pecandu narkotika, dimana keyakinan dari hakim sendiri harus kuat apakah menerapkan Pasal 127 (mengatur mengenai sanksi pidana) atau menerapkan ketentuan Pasal 103 (mengatur mengenai sanksi tindakan "rehabilitasi". Dikarenakan anak yang menyalahgunakan narkotika seharusnya direhabilitasi, apabila hakim menerapkan Pasal 127 dimana mengenai tentang sanksi pidana, anak yang melakukan penyalahguna narkotika harus dipidana maka hakim tidak melihat sisi lain dari Undang-Undang Narkotika sendiri yang mana anak yang melakukan penyalahguna narkotika wajib untuk direhabilitasi.

Menurut penulis pihak Kepolisaian Daerah Lampung sendiri harus tegas dan menegakkan Undang-Undang Narkotika sendiri, Dalam UndangUndang Nomor 35 Tahun 2009 Tentang Narkotika Pasal 54-59 menyebutkan tentang rehabilitasi:

Pasal 54

Pecandu Narkotika dan korban penyalahgunaan Narkotika wajib menjalani rehabilitasi medis dan rehabilitasi sosial.

Pasal 55

(1) Orang tua atau wali dari Pecandu Narkotika yang belum cukup umur wajib melaporkan kepada pusat kesehatan masyarakat, rumah sakit, dan/atau lembaga rehabilitasi medis dan rehabilitasi sosial yang ditunjuk oleh Pemerintah untuk mendapatkan pengobatan dan/atau perawatan melalui rehabilitasi medis dan rehabilitasi sosial.

(2) Pecandu Narkotika yang sudah cukup umur wajib melaporkan diri atau dilaporkan oleh keluarganya kepada pusat kesehatan masyarakat, rumah sakit, dan/atau lembaga rehabilitasi medis dan rehabilitasi sosial yang ditunjuk oleh Pemerintah untuk mendapatkan pengobatan dan/atau perawatan melalui rehabilitasi medis dan rehabilitasi sosial. 
(3) Ketentuan mengenai pelaksanaan wajib lapor sebagaimana dimaksud pada ayat (1) dan ayat (2) diatur dengan Peraturan Pemerintah.

Pasal 56

(1) Rehabilitasi medis Pecandu Narkotika dilakukan di rumah sakit yang ditunjuk oleh Menteri.

(2) Lembaga rehabilitasi tertentu yang diselenggarakan oleh instansi pemerintah atau masyarakat dapat melakukan rehabilitasi medis Pecandu Narkotika setelah mendapat persetujuan Menteri.

Pasal 57

Selain melalui pengobatan dan/atau rehabilitasi medis, penyembuhan Pecandu Narkotika sapat diselenggarakan oleh instansi pemerintah atau masyarakat melalui pendekatan keagamaan dan tradisional.

Pasal 58

Rehabilitasi sosial mantan Pecandu Narkotika diselenggarakan baik oleh instansi pemerintah maupun oleh masyarakat.

Pasal 59

(1) Pelaksanaan ketentuan sebagaimana dimaksud dalam Pasal 56 dan Pasal 57 diatur dengan Peraturan Menteri.

(2) Pelaksanaan ketentuan sebagaimana dimaksud dalam Pasal 58 diatur dengan peraturan menteri yang menyelenggarakan urusan pemerintahan di bidang sosial.

Maka dari itu Pasal yang mengenai rehabilitasi harus ditegakkan untuk bisa membuat anak yang menyalahgunakan narkotika bisa direhabilitasi bukan malah dipidana. Dan juga dari uraian diatas dari data yang ada anak yang direhabilitasi sangat rendah, berarti menunjukan bahwa implementasi rehabilitasi masih sedikit di implementasikan dan anak yang dipidana masih banyak yang seharusnya anak-anak tersebut dilakukan rehabilitasi dari pihak Kepolisian Daerah Lampung.

Berdasarkan analisis hasil penelitian dan pembahasan, dapat disimpulkan bahwa praktek rehabilitasi terhadap anak penyalahguna narkotika adalah praktek rehabilitasi terhadap anak penyalahguna narkotika masih belum sesuai dengan peraturan perundang-undangan yang ada yaitu :

a. Undang-Undang Republik Indonesia Nomor 35 Tahun 2009 tentang Narkotika.

b. Surat Edaran Mahkamah Agung (SEMA) Nomor 4 Tahun 2010 tentang Penempatan Penyalahguna, Korban Penyalahguna Kedalam Lembaga Medis dan Sosial. 
c. Peraturan Pemerintah (PP) Nomor 25 Tahun 2011 tentang Pelaksanaan Wajib Lapor Pecandu Narkotika untuk mendapatkan layanan terapi dan Rehabilitasi.

d. Peraturan Menteri Kesehatan Republik Indonesia Nomor 80 Tahun 2014 tentang petunjuk teknis pelaksanaan rehabilitasi medis bagi pecandu, penyalahguna, dan korban penyalahgunaan Narkotika yang sedang dalam proses penyidikan, penuntutan dan persidangan atau telah mendapatkan penetapan/putusan pengadilan.

e. Keputusan Menteri Kesehatan (kepmenkes) Nomor 1305/menkes/SK/VI/2011 yang menunjuk 131 Instansi Penerima Wajib Lapor (IPWL) di 33 Provinsi.

f. Peraturan Bersama Ketua Mahkamah Agung Republik Indonesia, Menteri Hukum dan Hak Asasi Manusia Republik Indonesia, Menteri Kesehatan Republik Indonesia, Jaksa Agung Republik Indonesia, Kepala Kepolisian Negara Republik Indonesia, Kepala Badan Narkotika Nasional Republik Nomor 01/ PB / MA/III/2014, Nomor 03 Tahun 2014, Nomor PER-005/A/JA/03/2014, Nomor 1 Tahun 2014, Nomor PERBER/01/III/2014/BNN tentang Penanganan Pecandu Narkotika dan Korban Penyalahgunaan Narkotika ke dalam Lembaga Rehabilitasi.

Dimana peraturan-peraturan ini seharusnya anak yang menyalahgunakan narkotika direhabilitasi tetapi ketentuan ini tidak pernah diterapkan, lebih banyak anak yang dipidana daripada direhabilitasi. Mengingat Pasal 56, 57, 58, 59 Tentang Narkotika mengusahakan pecandu narkotika dan korban penyalahguna narkotika wajib menjalani rehabilitas medis dan rehabilitas sosial sehingga anak-anak penyalahguna narkotika tidak mengalami kecanduan narkotika lagi, baik mental anak tersebut dilingkungan sosialnya.

\section{Hambatan Implementasi Rehabilitasi Kepolisian Daerah Lampung Terhadap Anak Penyalah Guna Narkotika}

Sistem pemidanaan terhadap penyalahgunaan narkotika tidak dapat dilepaskan dari sistem pemidanaan yang dianut dalam hukum Indonesia. Tujuan sistem pemidanaan pada operasionalnya adalah tujuan penegakan hukum yang dijalankan oleh sistem peradilan berdasarkan perangkatperangkat hukum yang mengatur kriminalisasi penyalahguna narkotika yaitu Undang-Undang Nomor 35 Tahun 2009 tentang Narkotika.

Menentukan tujuan pemidanaan pada sistem peradilan menjadi persoalan yang cukup dilematis, terutama dalam menentukan pemidanaan ditujukan untuk melakukan pembalasan atas tindak pidana yang terjadi atau merupakan tujuan yang layak dari proses pidana adalah pencegahan tingkah laku yang anti sosial. Hambatan implementasi rehabilitasi Polda Lampung 
terhadap anak penyalahguna narkotika dipengaruhi oleh beberapa faktor antara lain :

\section{a. Stuktur Hukum}

Direktorat Narkoba Polda Lampung mengenai implementasi rehabilitasi masih kurang optimal dan belum diterapkan rehabilitasi. Selain itu, kordinasi dengan BAPAS yang dibentuk atas perintah Undang-Undang Perlindungan Anak tidak dapat bertindak lebih banyak sebab hasil laporan BAPAS hanya berupa rekomendasi kepada penyidik dan tidak mengikat, sehingga terkadang masih dijumpai kasus anak berlanjut dan di putus di Pengadilan tanpa adanya penelitian dari BAPAS.

\section{b. Substansi Hukum}

Banyak peraturan seperti Undang-Undang dan Peraturan Pemerintah dan Peratutan Menteri yang seharusnya menjadi pertimbangan untuk anak penyalahguna narkotika dapat direhabilitasi dan mengingat anak didalam proses peradilan diatur dengan Undang-Undang tersendiri yaitu UndangUndang Sistem Peradilan Pidana Anak.

\section{c. Kultur Hukum}

Berdarkan wawancara dengan Prianto Teguh Nugroho mengatakan dalam undang-undang No 35 tahun 2009 tentang narkotika dijelaskan bahwa korban dan pecandu narkoba yang melaporkan diri atau dilaporkan keluarganya tidak ada dikenai tuntutan pidana namun hingga saat ini masih sedikit korban, pecandu atau keluarganya yang melaporkan untuk menjalani rehabilitasi mengingat hal tersebut masih dipandang sebagai aib atau keluarga merasa malu, jadi menurut penulis dapat disimpulkan derajat kepatuhan masyarakat terhadap hukum masih belum optimal misalnya saja dalam Undang-Undang Nomor 35 Tahun 2009 tentang Narkotika bahwa para pecandu atau pemakai narkotika tidak dipenjara (dihukum) oleh polisi apabila keluarga tersebut melaporkan/membawa anaknya ke pusat rehabilitasi, takutnya para orang tua akan rusaknya pencitraan mereka apabila diketahui anaknya adalah pecandu narkoba dan budaya nilai-nilai yang mendasari hukum berlaku dalam masyarakat yaitu konsepsi abstraksi hukum dalam berperan aktif mendukung implementasi rehabilitasi terhadap anak penyalahguna narkotika belum terwujud.

Peredaran Narkotika yang sangat pesat membuat Kepolisian Daerah Lampung kewalahan, dari hasil Wawancara Oleh Dir Narkoba yakni Bapak Prianto Teguh Nugroho selaku Kabag Binopsnal, pada tanggal 04 April 2016 menuturkan bahwa selama ini salah satunya yang membuat susahnya 
peredaran narkotika dikalangan masyarakat baik itu pelajar atau pekerja untuk di berantas yaitu dikarenakan adanya keberadaan narkotika yang sangat mudah didapatkan sehingga membuat seseorang sulit untuk kembali hidup normal antara lain:

1) Ketersedian yang dapat di beli dengan harga murah dan terjangkau

2) Mudah untuk mendapatkannya

3) Variasi jenis yang ada beragam dengan kemasan hemat atau kecil dan gampang disimpan membuat sindikat narkoba meluas, tidak di kawasan pelajar saja tetapi pekerja

4) Akses teknologi dan pergaulan bebas tanpa pengawasan orang tua serta pendidik

5) Perdagangan narkotika di kendalikan oleh sindikat yang kuat dan profesional. ${ }^{9}$

Melihat sangat mudahnya mendapatkan Narkotika di kalangan anak, remaja dan dewasa membuat Direktorat Narkoba Polda Lampung harus bekerja keras untuk memberantasnya, mengingat anak masih memiliki masa depan yang cerah untuk kehidupannya dan jangan sampai dengan mudah nya mendapatkan narkoba anak dapat menhancurkan masa depan anak.

Sistem pemasyarakatan diselenggarakan dalam rangka membentuk Warga Binaan Pemasyarakatan agar menjadi manusia seutuhnya, menyadari kesalahan memperbaiki diri dan tidak mengulangi tindak pidana sehingga dapat diterima kembali oleh lingkungan masyarakat serta dapat aktif kembali berperan dalam pembangunan dan hidup wajar sebagai warga yang baik dan bertanggung jawab.

Bidang pemidanaan pelaku pecandu narkotika secara umum masih menganut memperbaiki terpidana di Lembaga Pemasyarakatan sehingga memberikan gambaran bahwa kejahatan tersebut hanya terhenti sesaat dan akan muncul kembali kedalam lingkungan kehidupan sosial membuat tidak jera narapidana pengedar narkotika dan beredarnya barang haram itu di penjara. Kriminologi menerangkan bahwasanya kejahatan narkotika ini harus ada sanksi terobosan yang dapat menjadi efek jera bagi narapidana narkotika. Indonesia memiliki Undang-Undang Narkotika dan UndangUndang Pemasyarakatan yang sebetulnya representatif untuk dapat menciptakan sistem hukum ideal.

Terpidana pengguna narkotika dan korban penyalahguna dipulihkan di pusat rehabilitasi. "Sekarang mereka yang telah terbukti penyalahguna narkotika, sesuai Surat Edaran Mahkamah Agung RI Nomor 7 Tahun 2009 tentang Penempatan Penyalahguna Narkotika ke Pusat Terapi dan

\footnotetext{
${ }^{9}$ Wawancara Kabag Binopsnal Dir Narkoba Kepolisian Daerah Lampung, AKBP Prianto Teguh Nugroho, SIK., Senin, Tanggal 04 April 2016
} 
Rehabilitasi dengan demikian pengguna narkotika masuk ketempat rehabilitasi.

Berdasarkan hasil wawancara penyusun pada Senin, Tanggal 29 Maret 2016 dengan, Kepala Subsie bimbingan Klien Anak (BKA) yaitu Elvi Suryaningsih, beberapa faktor yang sulit untuk dihindari dalam pelaksanaan rehabilitasi berdasarkan penelitian terhadap pecandu Narkotika:

1) Adanya kesulitan dalam mengendalikan diri untuk melawan keinginankeinginan agar tidak terjerumus kembali dalam pengaruh buruk obat terlarang.

2) Adanya dampak mental merasa tidak percaya diri karena orang seringkali menggap sakaw putus obat, di lingkungan sekitar dirinya sebagai suatu tindakkan kriminal sehingga lebelisasi terhadap dirinya kerap membuat kesal dan merasa dikucilkan

3) Ketidaknyamanan berada di dalam masa pengobatan atau terapi, karena merasa sulit dalam beradaptasi.

Dari keterangan diatas dampak narkotika bukan hanya berupa fisik namun mental yang dapat memepengaruhi kehidupan sosial seseorang oleh karenanya harus disadari pemulihan ketergantungan terhadap obat-obatan terlarang harus ditangani secara benar, namun dengan adanya pemberian saksi minimum dan maksimum di dalam beberapa pasal membatasi seseorang, dengan tidak memperdulikan seseorang tersebut yang tidak mempunyai niatan melakukan tindak pidana narkotika seperti mengedarkan hanya terjerumus ketergantungan terhadap narkotika tersebut.

Undang-undang Nomor 35 Tahun 2009 Tentang Narkotika, menggunakan pendekatan pidana melakukan pengawasan dan pencegahan terhadap penyalahgunaan narkotika. Penggunaan pidana masih dianggap suatu upaya untuk menakut - menakuti agar tidak terjadinya penggunaan narkotika. Hal tersebut didukung dengan diberikannya kewenangan bagi BNN (Badan Nakotika Nasional) yang menjadi institusi yang berwenang untuk melakukan penyadaran kepada masyarakat, melakukan penyelidikan serta penuntutan dalam tindak pidana narkotika berdasarkan dari aturanaturan yang telah ada memberikan ancaman pidana penjara selama 1 tahun bila adanya kesengajaan tidak melaporkan tindak pidana narkotika.

Seiring dengan kondisi Lembaga Pemasyarakatan yang tidak mendukung pada saat ini karena dampak negatif keterpengaruhan prilaku kriminal lainnya dapat semakin memperburuk kondisi kejiwaan, kesehatan yang diderita para narapidana narkotika dan psikotropika akan semakin berat, keadaan ini diperlakukan dengan perbedaan di Lembaga Pemasyarkaan Narkotika karena yang menjadi penghuni di Lembaga Pemasyarakatan Narkotika secara khusus merupakan narapidana narkotika sehingga pola pembinaan di Lembaga Pemasyarkatan Narkotika adalah pembinaan yang konfrehensif antara pemulihan dengan pemidanaan. 
Pelaksanaan SEMA RI No. 07 tahun 2009 tentang Penempatan Penyalahguna Narkotika ke Pusat Terapi dan Rehabilitasi hakim tetap memperhatikan komposisi pemakaian sehingga pengguna dapat diputuskan untuk melaksanakan perawatan di tempat rehabilitasi. Penjelasan Pasal 56 dalam Undang-Undang Nomor 35 tahun 2009 tentang Undang-undang Narkotika disebutkan :

1) Ketentuan ini menegaskan bahwa rehabilitasi bagi pecandu narkotika dilakukan dengan maksud untuk memulihkan dan/atau mengembangkan kemampuan fisik, mental, dan sosial penderita yang bersangkutan.

2) Yang dimaksud dengan "instansi pemerintah misalnya Lembaga Pemasyarakatan Narkotika dan Pemerintah Daerah." Ketentuan ini menegaskan bahwa untuk rehabilitasi medis bagi pecandu narkotika pengguna jarum suntik dapat diberikan serangkaian terapi untuk mencegah penularan HIV/AIDS melalui jarum suntik dengan pengawasan ketat Departemen Kesehatan.

Pasal 57 Undang-Undang Nomor 35 tahun 2009 tentang Undangundang Narkotika menyebutkan selain pengobatan dan/atau rehabilitasi medis penyembuhan pecandu narkotika dapat diselenggarakan oleh instansi pemerintah atau masyarakat melalui pendekatan keagamaan dan tradisional, dengan ini Undang-Undang Nomor 35 Tahun 2009 tentang Undang-undang Narkotika memberi suatu pengertian bahwa pengguna narkotika sudah menjadi suatu penyakit bukan lagi menjadi suatu kriminal biasa sehingga untuk penanganannya perlu pengobatan untuk pemulihan maka di Lembaga Pemasyarakatan Narkotika. Sebagaimana pada Pasal 56 Undang-Undang nomor 35 tahun 2009 tentang Undang-undang Narkotika tersebut adalah sebagai instansi pemerintah dalam pelaksanaan rehabilitasi sosial.

Menyangkut Undang-undang Narkotika dalam pelaksanaan rehabilitasi untuk pembinaan, penyelenggaraan dan pembimbingan Warga Binaan Pemasyarakatan. Menteri dapat mengadakan kerjasama dengan instansi terkait, badan-badan kemasyarakan lainnya atau perorangan yang isi kegiatan seiring dengan penyelenggaraan sistem pemasyarakatan.

Rehabilitasi ini merupakan bagian dari sistem pembinaan yang digunakan untuk membantu seseorang melepaskan diri dari kecanduan dan merubah pelaku agar menjadi lebih baik dengan melakukan pembinaan dengan melatih kemampuan-kemapuan kreatifitas yang berdampak positif.

Berdasarkan paparan dari narasumber maka menurut penulis hambatan implementasi rehabilitasi polda lampung adalah faktor Struktur Hukum mengenai implementasi rehabilitasi masih kurang optimal dan belum diterapkan rehabilitasi, Substansi Hukum keseluruhan aturan hukum, norma hukum dan asas hukum, baik yang tertulis maupun tidak tertulis, termasuk putusan pengadilan, Struktur Hukum opini-opini, kepercayaan-kepercayaan (keyakinan-keyakinan), kebiasaan-kebiasaan, cara berpikir, dan cara 
bertindak, baik dari para penegak hukum maupun dari warga masyarakat, tentang hukum dan berbagai fenomena yang berkaitan dengan hukum, yang mana didalam hambatan implementasi rehabilitasi pada Polda Lampung sendiri sangat berat untuk menegakan peraturan itu sendiri dan penegak hukumnya yang terkadang tidak mau menerapkan implementasi rehabilitasi terhadap anak penyalahguna narkotika.

Berdasarkan wawancara juga dengan Kepala Subsie bimbingan klien anak (BKA) penulis simpulkan, kurangnya pengetahuan masyarakat khususnya para keluarga pecandu narkoba, bahwa dalam Undang-Undang Nomor 35 Tahun 2009 tentang Narkotika bahwa para pecandu atau pemakai narkotika tidak dipenjara (dihukum) oleh polisi apabila keluarga tersebut melaporkan/membawa anaknya ke pusat rehabilitasi, takutnya para orang tua akan rusaknya pencitraan mereka apabila diketahui anaknya adalah pecandu narkoba.

\section{Upaya Kepolisian Daerah Lampung Mengatasi Kendala Rehabilitasi Terhadap Anak Penyalah Guna Narkotika}

Untuk implementasi pelaksanaan pasal 127 Undang - Undang Nomor 35 Tahun 2009 maka Mahkamah Agung, Kejaksaan Agung, Kepolisian, Kementerian Hukum dan Hak Asasi Manusia, Kementerian Kesehatan, Kementerian Sosial dan BNN menandatangani Peraturan Bersama Nomor 01 Tahun 2014 tentang Penanganan Pecandu Narkotika dan Korban Penyalahgunaan Narkotika dalam Lembaga Rehabilitasi pada tanggal 11 Maret 2014. Adapun tujuan ditandatangani peraturan bersama ini adalah: ${ }^{10}$

a. Mewujudkan koordinasi dan kerjasama secara optimal penyelesaian permasalahan narkotika dalam rangka menurunkan jumlah pecandu narkotika dan korban penyalahgunaan narkotika melalui program pengobatan, perawatan dan pemulihan dalam penanganan pecandu dan korban penyalahgunaan narkotika sebagai tersangka, terdakwa atau narapidana.

b. Menjadi pedoman teknis dalam penanganan pecandu narkotika dan korban penyalahgunaan narkotika sebagai tersangka, terdakwa, atau narapidana untuk menjalani rehabilitasi medis dan/atau rehabilitasi social.

Peraturan bersama ini mempersyaratkan untuk membentuk Tim Asesmen Terpadu agar seseorang yang ditangkap oleh penegak hukum dapat diketahui ketergantungannya terhadap narkotika dan diketahui pula peran yang bersangkutan dalam tindak pidana narkotika yang dilakukan, yaitu sebagai korban penyalahgunaan narkotika atau sebagai pengedar/bandar

10 http://www.depkes.go.id/resources/download/pusdatin/buletin/buletin-napza.pdf, (diakses Rabu, 06 April 2016 pukul 11.00 WIB). 
atau sebagai pecandu yang merangkap pengedar/bandar. Tim Asesmen Terpadu ini adalah tim yang terdiri dari tim dokter/medis (meliputi dokter dan psikolog) dan tim hukum (meliputi POLRI, BNN, Kejaksaan dan Kementerian Hukum dan Hak Asasi Manusia) yang ditetapkan oleh pimpinan satuan kerja setempat berdasarkan Surat Keputusan Kepala Badan Narkotika Nasional, Badan Narkotika Provinsi, Badan Narkotika Kabupaten/Kota.

Tim Asesmen Terpadu memiliki kewenangan untuk melakukan analisis peran seseorang yang ditangkap/tertangkap tangan apakah seseorang tersebut sebagai korban penyalahgunaan narkotika/pecandu atau pengedar narkotika atas permintaan penyidik, menentukan kriteria tingkat keparahan penggunaan narkotika sesuai dengan jenis kandungan yang dikonsumsi, situasi dan kondisi ketika ditangkap pada tempat kejadian perkara, dan merekomendasi rencana terapi dan rehabilitasi terhadap pengguna narkotika.

Selain itu Tim Asesmen Terpadu memiliki tugas untuk melakukan analisis terhadap seseorang yang ditangkap dan/atau tertangkap tangan dalam kaitan peredaran gelap narkotika; asesmen dan analisis medis, psikososial, serta merekomendasi rencana terapi dan rehabilitasi seseorang.

Dengan adanya Tim Asesmen Terpadu, perlu adanya mekanisme dalam penilaian pecandu narkotika dan korban penyalahgunaan narkotika sebagai tersangka dan/atau terdakwa dalam penyalahgunaan narkotika yang sedang menjalani proses penyidikan, penuntutan, dan persidangan di pengadilan sehingga dapat diberikan pengobatan, perawatan dan pemulihan pada lembaga rehabilitasi medis dan/atau lembaga rehabilitasi sosial.

Peraturan bersama ini selanjutnya ditindaklanjuti oleh kementerian dan lembaga terkait dalam peraturan bersama, khususnya dalam:

a. Pembentukan Tim Asesmen Terpadu (TAT);

b. Mekanisme penempatan pecandu selama proses hukum;

c. Mekanisme penempatan pecandu setelah putusan hakim.

Menurut Dir Reserse Narkoba Polda Lampung upaya penanggulangan yang dilakukakn Kepolisia Daerah Lampung dalam mengatasi kendala anak penyalahguna narkoba anatara lain yakni preemtif, preventif, dan represif. Ketiga hal ini merupakan fungsi - fungsi utama (operasional) sesuai dengan tugas pokok Polri yang diatur dalam pasal 13 UU No. 2 Tahun 2002 tentang Kepolisian Republik Indonesia.

\section{a. Upaya Preemtif}

Upaya preemtif adalah upaya pencegahan yang dilakukan secara dini, antara lain mencakup pelaksanaan kegiatan penyuluhan yang bersifat dengan sasaran untuk memengaruhi faktor-faktor penyebab pendorong dan faktor peluang (Faktor Korelatif Kriminogen) dari adanya kejahatan tersebut. Sehingga akan tercipta suatu kondisi kesadaran kewaspadaan dan daya 
tangkal serta terbina dan terciptanya kondisi perilaku dan norma hidup bebas dari segala ancaman narkoba. Menyikapi maraknya penyalahgunaan narkoba, upaya preemtif merupakan salah satu kegiatan operasional yang dilakukan oleh Reserse Narkoba Polda Lampung. ${ }^{11}$ Contohnya sudah dilakukan kegiatan penyuluhan, penyebaran pamphlet, pemasanagan spanduk anti narkoba.

\section{b. Upaya Preventif}

Tindakan preventif sebagaimana dikatakan Prianto Teguh Nugroho, merupakan pelaksanaan fungsi kepolisian yang diarahkan kepada upaya pencegahan terjadinya gangguan kamtibmas. Adapun penanganan secara preventif yang dapat dilakukan adalah dengan meningkatkan kegiatan kepolisian. Dalam pencegahan masalah tindak pidana narkoba, pihak Satuan Narkoba melakukan Operasi Rutin Kepolisian dan Operasi Khusus Kepolisian. Contohnya sudah dilakukan kegiatan razia tempat-tempat yang diduga menjadi tempat transaksi dan penyalahgunan narkoba, razia kendaraan serta razia di daerah perbatasan atau Seaport Interdiction Pelabuhan Bakauheni.

\section{c. Upaya Represif}

Upaya represif dimulai ketika polisi mendapatkan informasi mengenai terjadinya tindak kejahatan. Sumber informasi tersebut bisa berasal dari laporan masyarakat, media massa, diketahui langsung oleh aparat, maupun data yang diberikan oleh intelijen kepolisian. Mengenai informasi yang berasal dari data intelijen kepolisian dan laporan masyarakat. Contohnya melakukan kegiatan penegakan hukum dengan melakukan penangkapa terhadap pelaku tindak kejahatan narkoba serta membongkar jaringan sindikatnya.

Berdasarkan uraian diatas dapat dianalisis upaya kepolisian daerah lampung mengatasi kendala anak penyalahguna narkotika dengan melakukan preemtif, preventif, dan represif dimana upaya ini dilakukan terus menerus agar anak dan penyalahguna narkotika lainnya memahami hukuman yang diberikan apabila menyalahgunakan narkotika sehingga dari uraian diatas anak dan penyalahguna narkotika lainya bisa memahami tentang dampak buruk penyalahguna narkotika dan ganjaran hukuman yang didapatkannya nanti.

Upaya kepolisan Daerah Lampung Sendiri semenjak ada pertauran bersama tentang Asesmen apabila ada anak penyalahguna narkotika langsung membuat pembentukan tim Assesmen terpadu, mekanisme

\footnotetext{
${ }^{11}$ Wawancara Kabag Binopsnal Reserse Polda Lampung, AKBP Prianto Teguh, SIK.
} 
penempatan pecandu selama proses hukum, mekanisme penempatan pecandu setelah putusan hakim. Dimana tim Assesmen terpadu ini adalah tim yang terdiri dari tim dokter/medis (meliputi dokter dan psikolog) dan tim hukum (meliputi POLRI, BNN, Kejaksaan dan kementerian Hukum dan Hak Asasi Manusia), dimana juga tim Assesmen terpadu ini juga memiliki kewenangan untuk melakukan analisis peran seseorang yang ditangkap/tertangkap tangan apakah seseorang tersebut sebagai korban penyalahguna narkotika/pecandu atau pengedar narkotika yang selanjutnya akan merekomendasikan penyalaguna narkotika tersebut untuk diterapi dan direhabilitasi.

Upaya Kepolisian Daerah Lampung mengatasi kendala anak penyalahguna narkotika adalah melakukan upaya preemtif, preventif, dan represif dimana upaya ini dilakukan terus menerus agar anak dan penyalahguna narkotika lainnya memahami hukuman yang diberikan apabila menyalahgunakan narkotika sehingga dari uraian diatas anak dan penyalahguna narkotika lainya bisa memahami tentang dampak buruk penyalahguna narkotika dan ganjaran hukuman yang didapatkannya nanti.

\section{Penutup}

1. Simpulan

Berdasarkan analisis hasil penelitian dan pembahasan, dapat disimpulkan bahwa praktek rehabilitasi terhadap anak penyalahguna narkotika sebagai berikut:

a. Praktek rehabilitasi terhadap anak penyalahguna narkotika masih belum sesuai dengan peraturan perundang-undangan yang ada yaitu dimana peraturan-peraturan yang ada seharusnya anak yang menyalahgunakan narkotika direhabilitasi tetapi ketentuan ini tidak pernah diterapkan, lebih banyak anak yang dipidana daripada direhabilitasi. Mengingat Pasal 56, 57, 58, 59 Tentang Narkotika mengusahakan pecandu narkotika dan korban penyalahguna narkotika wajib menjalani rehabilitas medis dan rehabilitas sosial sehingga anak-anak penyalahguna narkotika tidak mengalami kecanduan narkotika lagi, baik mental anak tersebut dilingkungan sosialnya.

b. Hambatan implementasi rehabilitasi polda lampung terhadap anak penyalahguna narkotika dipengaruhi oleh beberapa faktor antara lain:

1). Stuktur Hukum

Direktorat Narkoba Polda Lampung mengenai implementasi rehabilitasi masih kurang optimal dan belum diterapkan rehabilitasi. Selain itu, kordinasi dengan BAPAS yang dibentuk atas perintah Undang-Undang Perlindungan Anak tidak dapat bertindak lebih banyak 
sebab hasil laporan BAPAS hanya berupa rekomendasi kepada penyidik dan tidak mengikat, sehingga terkadang masih dijumpai kasus anak berlanjut dan di putus di Pengadilan tanpa adanya penelitian dari BAPAS. 2). Kultur Hukum

Derajat kepatuhan masyarakat terhadap hukum masih belum optimal misalnya saja dalam Undang-Undang Nomor 35 Tahun 2009 tentang Narkotika bahwa para pecandu atau pemakai narkotika tidak dipenjara (dihukum) oleh polisi apabila keluarga tersebut melaporkan/membawa anaknya ke pusat rehabilitasi, takutnya para orang tua akan rusaknya pencitraan mereka apabila diketahui anaknya adalah pecandu narkoba dan budaya nilai-nilai yang mendasari hukum berlaku dalam masyarakat yaitu konsepsi abstraksi hukum dalam berperan aktif mendukung implementasi rehabilitasi terhadap anak penyalahguna narkotika belum terwujud.

c. Upaya Kepolisian Daerah Lampung mengatasi kendala anak penyalahguna narkotika adalah melakukan upaya preemtif, preventif, dan represif dimana upaya ini dilakukan terus menerus agar anak dan penyalahguna narkotika lainnya memahami hukuman yang diberikan apabila menyalahgunakan narkotika sehingga dari uraian diatas anak dan penyalahguna narkotika lainya bisa memahami tentang dampak buruk penyalahguna narkotika dan ganjaran hukuman yang didapatkannya nanti.

\section{Saran}

a. Kepolisian Daerah Lampung seharusnya lebih menekankan kepada anak penyalahguna narkotika untuk direhabilitasi karena sudah ada aturan yang jelas seperti Undang-Undang Narkotika Nomor 35 Tahun 2009, Undang-undang Nomor 11 Tahun 2012 Tentang Sistem peradilan Pidana Anak, Undang-Undang Nomor 35 Tahun 2014 tentang Perlindungan Anak, Surat Edaran Mahkamah Agung, Peraturan Pemerintah (PP) tentang Pelaksanaan Wajib Lapor, serta Peraturan Menteri Kesehatan tentang petunjuk teknis pelaksanaan rehabilitasi.

b. Pemerintah sebaiknya memaksimalkan fungsi-fungsi lembaga-lembaga sosial berhubungan dengan implementasi rehabilitasi terhadap anak penyalahguna narkotika, posisi BAPAS juga harus diikutsertakan dan harus mempunyai andil yang kuat untuk bisa merekomendasikan penelitiannya yang diharapkan mampu meminimalisir hambatanhambatan yang timbul dalam implementasi rehabilitasi terhadap anak penyalahguna narkotika.

c. Upaya Kepolisian Daerah Lampung harus ditingkatkan kembali didalam melakukan Upaya preemtif, preventif, dan represif, dan sebaiknya dari 
Pemerintah juga harus ikut andil dan memaksimalkan upaya sosialisai untuk pencegahan terhadap penyalahgunaan narkotika.

\section{Daftar Pustaka}

\section{A. Buku}

AR., Sujono dan Bony, Daniel. (2011). Komentar dan Pembahasan Undangundang Nomor 35 Tahun 2009 tentang Narkotika. Jakarta: Sinar Grafika.

Arif, Gosita. (2009). Masalah Perlindungan Anak. Bandung: Mandar Maju. Kusno, Adi. (2009). Kebijakan Kriminal Dalam Penanggulangan Tindak Pidana Narkotika Oleh Anak. Malang: UMM Press. . (2009). Diversi Sebagai Upaya Alternatif Penanggulangan Tindak Pidana Narkotika Oleh Anak. Malang: UMM Press.

Makarao, Moh. Taufik, Suhasril, dan A.S, Moh. Zakky. (2003). Tindak Pidana Narkotika. Jakarta: Ghalia Indonesia.

\section{B. Sumber Lain}

http://www.depkes.go.id/resources/download/pusdatin/buletin/buletinnapza.pdf, diakses pada hari rabu, 06 April 2016 jam 11.00 WIB. 